\title{
Long-term litter type treatments alter soil carbon composition but not microbial carbon utilization in a mixed pine-oak forest
}

\author{
Xiaowei Guo $\cdot$ Zhongkui Luo $\cdot$ Osbert Jianxin Sun $\mathbb{C}$
}

Received: 28 September 2020/ Accepted: 12 January 2021 / Published online: 25 January 2021

(C) The Author(s) 2021

\begin{abstract}
Changes in litter and nutrient inputs into soil could have significant consequences on forest carbon (C) dynamics via controls on the structure and microbial utilization of soil organic C (SOC). In this study, we assessed changes in physical fractions (250-2000 $\mu \mathrm{m}, 53-250 \mu \mathrm{m}$, and $<53 \mu \mathrm{m}$ soil aggregates) and chemical fractions (labile, intermediate and recalcitrant pools) of SOC in the top $20 \mathrm{~cm}$ mineral soil layer and their influences on microbial substrate utilization after eight years of experiment in a mixed pine-oak forest. The litter treatments included: control $\left(\mathrm{L}_{\mathrm{con}}\right)$, litter removal $\left(\mathrm{L}_{\text {nil }}\right)$, fine woody litter addition $\left(\mathrm{L}_{\text {woody }}\right)$, leaf litter addition $\left(\mathrm{L}_{\text {leaf }}\right)$ and a mix of leaf and fine woody litter $\left(\mathrm{L}_{\text {mix }}\right)$. Nitrogen $(\mathrm{N})$ addition (application rates of 0,5 and $10 \mathrm{~g} \mathrm{~N} \mathrm{~m}^{-2}$ year $^{-1}$, respectively) was also applied. We found that complete removal of forest-floor litter $\left(\mathrm{L}_{\text {nil }}\right)$ significantly reduced the pool sizes of all SOC fractions in both the
\end{abstract}

Responsible Editor: Myrna Simpson.

Supplementary Information The online version contains supplementary material available at https://doi.org/10.1007/ s10533-021-00757-z.

X. Guo · O. J. Sun $(\bowtie)$

School of Ecology and Nature Conservation, Beijing

Forestry University, Beijing 100083, China

e-mail: sunjianx@bjfu.edu.cn

Z. Luo

College of Environmental and Resource Sciences, Zhejiang University, Zhejiang 310058, China physical and chemical fractions compared with treatments that retained either leaf litter $\left(\mathrm{L}_{\text {leaf }}\right)$ or mixture of leaves and fine woody materials $\left(\mathrm{L}_{\text {mix }}\right)$. The type of litter was more important in affecting SOC fractions than the quantity of inputs; neither the level of $\mathrm{N}$ addition rate nor its interaction with litter treatment had significant effects on both physical and chemical SOC fractions. Microbial respiration differed significantly among the treatments of varying litter types. However, the effectiveness of microbial $\mathrm{C}$ utilization inferred by microbial $\mathrm{C}$ use efficiency and biomassspecific respiration was not affected by either the litter treatments or $\mathrm{N}$ addition. These results suggest that despite significant changes in SOC composition due to long-term treatments of forest-floor litter and $\mathrm{N}$ addition in this mixed pine-oak forest of temperate climate, microbial $\mathrm{C}$ utilization strategies remain unaffected.

Keywords Carbon pools - Carbon fractions - Plant Litter · Nitrogen deposition - Microbial respiration . Soil organic carbon

\section{Introduction}

The amount of carbon (C) stored in soil worldwide far exceeds the amount of carbon stored in plants and the atmosphere combined (Scharlemann et al. 2014), and 
it is very sensitive to global change factors, such as $\mathrm{CO}_{2}$ fertilization effect-enhanced plant growth and nitrogen $(\mathrm{N})$ deposition-induced changes in soil nutrient availability (Thornton et al. 2007). Plant litter play a vital role in determining soil organic C (SOC) storage and cycling in forest ecosystems, as some of them are translocated to mineral soil as particulate or dissolved organic matter, and transformed to various physical components (i.e., organic $\mathrm{C}$ occluded in soil aggregates of different sizes) and chemical fractions (i.e., labile and recalcitrant organic $\mathrm{C}$ determined by chemical structure) (Schmidt et al. 2011; Cotrufo et al. 2013). However, the effects of litter on SOC dynamics are inconsistent, depending on litter quantity and quality and soil conditions (von Haden et al. 2019). For example, the associated processes of mineralization and stabilization of lignin, cellulose and other compounds through a series of actions by microorganisms are the major pathways of litter decomposition; the performance of these processes is dependent of the abiotic conditions like soil temperature and moisture, and biotic factors such as chemical composition of litter and soil organisms (Krishna and Mohan 2017). A modelling study by Castellano et al. (2015) suggested that the effect of litter quality on SOC stabilization depends on the extent of soil $\mathrm{C}$ saturation. von Haden et al. (2019) found that high litter input and low litter C:N ratios (which is typically associated with higher litter quality) stimulated SOC storage in soil aggregates and mineral-associated fractions. Fresh litter inputs may also cause soil priming (Kuzyakov et al. 2000), such that soil C replenishment by new litter input may be offset by the primed decomposition of native soil C (Sayer et al. 2011; Cotrufo et al. 2013; Lajtha et al. 2018). But it remains an open question if the litter inputs of differential quality and quantity would affect the stability of soil carbon storage through modification of the SOC composition. Elucidation of the associations of litter inputs with various physical and chemical SOC fractions will help gain better insight in the regulation of SOC dynamics by litter production and variations.

Nutrient availability represented by $\mathrm{N}$ is another important factor modulating the distribution and turnover of SOC fractions (e.g., physical aggregation and chemical recalcitrance). Soil $\mathrm{N}$ availability directly affects soil $\mathrm{pH}$, enzyme activities, and microbial substrate availability and community structure (Treseder 2008). For example, soil acidification caused by $\mathrm{N}$ deposition could inhibit soil microbial metabolism (Treseder 2008). In N-limited systems, however, $\mathrm{N}$ deposition may relax $\mathrm{N}$ limitation (Reay et al. 2008), thus accelerating microbial utilization of labile organic C (Tian et al. 2016). In addition, increased soil $\mathrm{N}$ availability may also directly increase litter decomposition due to the increased soil enzyme activity (Manning et al. 2008). However, it is still uncertain whether and how $\mathrm{N}$ availability interacts with litter quantity and quality to affect soil physical and chemical $\mathrm{C}$ fractions in situ under natural environmental conditions. A major reason for such uncertainty is due to the fact that the total impacts on SOC dynamics result from the sum of effects across physically and chemically distinct SOC pools (Neff et al. 2002), which may respond differently to changing conditions. Different SOC pools have distinct turnover timescales due to physical protection which is partly determined by soil structure and mineralogy (Schmidt et al. 2011), biochemical resistance to degradation, and/or selective utilization by different microbial functional groups (von Lützow et al. 2006; Shen et al. 2018; Luo et al. 2020). Overall, our understanding on how SOC composition responds to changes in long-term $\mathrm{C}$ and nutrient inputs needs improvement and to some extent, constrains our ability to reliably predict long-term SOC dynamics.

Potential SOC composition changes under altered $\mathrm{C}$ and nutrient inputs may shape the structure and functioning of microbial decomposer communities (Cotrufo et al. 2013). Several studies have shown that soil microorganisms can adapt to changes in $\mathrm{C}$ substrates by adjusting their community structure, metabolism, and substrate utilization strategies (Goldfarb et al. 2011; Sinsabaugh et al. 2013). Apart from the regulating effects of SOC composition on the microbial processes, microbial metabolism changes in turn may also affect SOC composition via changed microbial necromass, which is an important component of SOC (Kallenbach et al. 2015, 2016; Ludwig et al. 2015; Liang et al. 2017). Due to the complexity of SOC compound fractions and microbial decomposition processes involved in the decomposition of those SOC fractions, the connections between the dynamics of SOC fractions and microbial metabolisms are rarely investigated.

We conducted a long-term experiment with altered litter inputs and varying level of $\mathrm{N}$ addition in a mixed pine (Pinus tabulaeformis Carr.) and oak (Quercus 
wutaishanica Mayr) forest of northern China. The litter treatments included: control $\left(\mathrm{L}_{\text {con }}\right)$, litter removal $\left(\mathrm{L}_{\text {nil }}\right)$, fine woody litter addition $\left(\mathrm{L}_{\text {woody }}\right)$, leaf litter addition $\left(\mathrm{L}_{\text {leaf }}\right)$ and a mix of leaf and fine woody litter $\left(\mathrm{L}_{\text {mix }}\right)$. $\mathrm{N}$ addition was applied at 0,5 and $10 \mathrm{~g} \mathrm{~N} \mathrm{~m}^{-2}$ year $^{-1}$ in the form of urea. The objectives of our study were to address the question that how changes in litter and $\mathrm{N}$ inputs would influence physical and chemical component fractions of SOC, and to determine whether and how potential changes in SOC composition would affect microbial C utilization. We hypothesized that increases in both quantity and quality (e.g. woody materials vs leaves) of forestfloor litter inputs alter SOC composition, and this alteration is further modulated by $\mathrm{N}$ addition because of increased nutrient availability for microbial energy acquisition (i.e., assimilation of different SOC fractions). Due to microbial $\mathrm{C}$ use efficiency (CUE) increases with increasing soil $\mathrm{C}$ and $\mathrm{N}$ availability (Sinsabaugh et al. 2013), we further hypothesized that microbial CUE is enhanced under the conditions of high substrate ( $\mathrm{C}$ and $\mathrm{N}$ ) availability after eight years of experimental treatments.

\section{Materials and methods}

\section{Study site and experimental design}

This study was conducted at a natural forest site in Taiyue Mountains of Shanxi province, China (latitude $33^{\circ} 39^{\prime} \mathrm{N}$, longitude $112^{\circ} 07^{\prime} \mathrm{E}$, elevation $1500 \mathrm{~m}$ a.s.l.). It is in a region with a warm temperate and semihumid continental monsoon climate, with a mean annual temperature of $8.6^{\circ} \mathrm{C}$, and a mean annual precipitation of $662 \mathrm{~mm}$. About $60 \%$ of the precipitation falls during the period from July to September (Sun et al. 2016). The soil belongs to brown forest soils developed from limestone with a $\mathrm{pH}$ of $6.85,7.02$ and 7.47 in $0-5 \mathrm{~cm}, 5-10 \mathrm{~cm}$ and $10-20 \mathrm{~cm}$ soil layers, respectively. The soil type is classified as Alfisols according to the international soil classification system (IUSS Working Group WRB 2014). The surface soil $(0-20 \mathrm{~cm})$ contains $68.73 \mathrm{~g} \mathrm{~kg}^{-1}$ organic $\mathrm{C}$ and $4.84 \mathrm{~g} \mathrm{~kg}^{-1}$ total $\mathrm{N}$. The litter is typically composed of leaves, fine branches, and fruiting bodies (mainly pinecones and oak seeds) on forest floor, with average density of 366,158 and $253 \mathrm{~g} \mathrm{~m}^{-2}$ year $^{-1}$, respectively.
A field experiment with a randomized block design involving four types of litter treatments and three levels of $\mathrm{N}$ addition rate was established in 2009 in a mixed pine ( $P$. tabulaeformis) and oak ( $Q$. wutaishanica) stand with very little understory growth. There were five blocks laid out over a distance of $40 \mathrm{~m}$ along the contour and $10 \mathrm{~m}$ along the slope, with adjacent blocks separated by a $1 \mathrm{~m}$ gap. Within each block, combinations of litter type treatments and $\mathrm{N}$ addition rates were randomly assigned to $122 \times 2 \mathrm{~m}$ plots separated by minimum distance of $0.5 \mathrm{~m}$. The four litter type treatments were aligned with the modified DIRT (the detrital input and removal treatment) project (Lajtha et al. 2018), including (1) complete removal of forest-floor litter $\left(\mathrm{L}_{\mathrm{nil}}\right)$, (2) placement of fine woody litter of twice the natural density $\left(\mathrm{L}_{\text {woody }}\right)$, (3) placement of leaf litter of twice the natural density $\left(\mathrm{L}_{\text {leaf }}\right)$, and (4) placement of mixed leaf and fine woody litter of twice the natural density $\left(\mathrm{L}_{\text {mix }}\right)$. Specifically, all forest-floor litter on $\mathrm{L}_{\text {nil }}$ plots were collected and transferred to $\mathrm{L}_{\text {mix }}$ plots, whilst leaf litter and fine woody litter were sorted and exchanged between $\mathrm{L}_{\text {woody }}$ and $\mathrm{L}_{\text {leaf }}$ plots. Another group of five $2 \times 2 \mathrm{~m}$ plots adjacent to the treatment plots were set up as controls of natural site conditions, designated as $\mathrm{L}_{\mathrm{con}}$. As a result of the differential litter regimes, the litter type treatment plots are distinguishable in terms of litter quality and quantity. For example, litter dry mass $\left(\mathrm{kg} \mathrm{m}^{-2}\right)$ in $\mathrm{L}_{\text {woody }}$ plots was significantly lower than that in $\mathrm{L}_{\text {leaf }}$ and $\mathrm{L}_{\text {mix }}$ plots. However, the litter in $\mathrm{L}_{\text {woody }}$ plots had significantly higher $\mathrm{C}: \mathrm{N}$ and acidinsoluble materials (AIM) to nitrogen (AIM:N) ratios than in $\mathrm{L}_{\text {mix }}$ and $\mathrm{L}_{\text {leaf }}$ plots; whilst the C:N and AIM: $\mathrm{N}$ ratios were comparable between $\mathrm{L}_{\text {leaf }}$ and $\mathrm{L}_{\text {mix }}$ plots (Sun et al. 2016). Three levels of $\mathrm{N}$ addition rate were interactively incorporated with the litter type treatments, including $0\left(\mathrm{~N}_{0}\right), 5\left(\mathrm{~N}_{5}\right)$ and $10\left(\mathrm{~N}_{10}\right) \mathrm{g} \mathrm{N}$ $\mathrm{m}^{-2}$ year $^{-1}$, applied as urea. At each time of plot maintenance, one quarter of total urea required to be applied each year was mixed with $\sim 500 \mathrm{~g}$ soil collected from the corresponding plot, and sprinkled evenly across the plot. The plots were tended, mainly for sorting the litter and applying $\mathrm{N}$, four times a year, in April, June, August, and October, respectively.

Soil sampling and physicochemical properties

In August 2017, the litter layer was carefully cleared before soil sampling. Soil samples were extracted 
using a soil auger with $3 \mathrm{~cm}$ inner diameter from 5 random points on each plot, and mixed to yield one composite sample per plot. Each core was split into three soil layers: $0-5 \mathrm{~cm} ; 5-10 \mathrm{~cm}$ and $10-20 \mathrm{~cm}$. Visible litter, roots, and stones were carefully removed. The soil samples were stored in airtight polypropylene bags and placed in a cooler filled with ice-cubes during transportation to the laboratory. The composite sample was divided into two subsamples in laboratory: one air-dried for determining soil physicochemical properties, and the other temporarily stored at $-20{ }^{\circ} \mathrm{C}$ for later measurements of microbial properties.

Using the air-dried samples, soil total $\mathrm{N}(\mathrm{TN})$ was analyzed using semimicro-Kjeldahl (UDK159, VELP, Italy). Soil $\mathrm{NH}_{4}^{+}-\mathrm{N}$ and $\mathrm{NO}_{3}^{-}-\mathrm{N}$ were analyzed colorimetrically by a continuous flow analyzer (SEAL AA3, Norderstedt, Germany). Dissolved organic C and $\mathrm{N}$ (DOC and DON) was determined by measuring $\mathrm{C}$ and $\mathrm{N}$ concentration in the $0.5 \mathrm{~mol} \mathrm{~L}^{-1} \mathrm{~K}_{2} \mathrm{SO}_{4}$ extract solution (soil:solution $=1: 4$ ) after filtering through a membrane filter with $0.45-\mu$ m pores using Multi 3100 N/C TOC analyzer (Analytik Jena, Germany).

Physical and chemical fractionations of SOC

Using the air-dried samples, soil aggregates were separated based on the method by Six et al. (1998). Briefly, $20 \mathrm{~g}$ soil was placed in a nest of sieves of $2000 \mu \mathrm{m}, 250 \mu \mathrm{m}$ and $53 \mu \mathrm{m}$. Then the macro (250-2000 $\mu \mathrm{m})$, micro $(53-250 \mu \mathrm{m})$ and mineral size $(<53 \mu \mathrm{m})$ aggregates were separated and collected by shaking the sieves with 12 glass beads of $6 \mathrm{~mm}$. Organic $\mathrm{C}$ content in these aggregates (named Macro$\mathrm{C}$, Micro-C and Mineral-C, respectively) was measured using the Vario ELIII Elemental Analyzer (Elementar, Germany). The percentage of Macro-C (fMacro-C), Micro-C (fMicro-C) and Mineral-C (fMineral-C) in total SOC (TOC) was calculated. The soil samples were treated with diluted $\mathrm{HCl}$ to remove the inorganic $\mathrm{C}$ prior to the determination.

Two-step hydrolysis with $\mathrm{H}_{2} \mathrm{SO}_{4}$ (Rovira and Vallejo 2002) was applied to determine the chemical fractions of SOC. Briefly, $500 \mathrm{mg}$ of ground soil sample was hydrolyzed with $20 \mathrm{~mL}$ of $2.5 \mathrm{~mol} \mathrm{~L}^{-1}$ $\mathrm{H}_{2} \mathrm{SO}_{4}$ at $105{ }^{\circ} \mathrm{C}$ for $30 \mathrm{~min}$. Then the hydrolyzed solution was centrifuged for $10 \mathrm{~min}$ at a speed of 5000 rmp $\min ^{-1}$. The supernatant hydrolysate was collected to a $50 \mathrm{~mL}$ tube. The soil residues were further rinsed with $20 \mathrm{~mL}$ of deionized water and centrifuged, and the supernatant hydrolysate added to the $50 \mathrm{~mL}$ tube. Carbon content in the hydrolysate of the $50 \mathrm{~mL}$ tube was measured using Multi $3100 \mathrm{~N} / \mathrm{C}$ TOC analyzer. This carbon was treated as labile organic C (LOC) as it mainly includes polysaccharides of plant- and microbe-origins, which usually decompose rapidly and readily available for microbial consumption (Oades et al. 1970). The remaining soil residues were hydrolyzed and shacked overnight with $2 \mathrm{~mL}$ of $13 \mathrm{~mol} \mathrm{~L}^{-1} \mathrm{H}_{2} \mathrm{SO}_{4}$ at room temperature, and then deionized water was added to dilute $\mathrm{H}_{2} \mathrm{SO}_{4}$ concentration to $1 \mathrm{~mol} \mathrm{~L}^{-1}$. The diluted hydrolysate was kept at $105{ }^{\circ} \mathrm{C}$ for $3 \mathrm{~h}$, and then centrifuged for $10 \mathrm{~min}$. The supernatant hydrolysate was measured for $\mathrm{C}$ content, and regarded as intermediate organic $\mathrm{C}$ (IOC). The remaining soil residues were measured for C content using Vario EL III Elemental Analyzer, which is the $\mathrm{C}$ retained in the soil that cannot be hydrolyzed by the two preceding steps and treated as recalcitrant organic C (ROC) (Oades et al. 1970), i.e., mineral-associated or chemically recalcitrant organic C. We also calculated the proportion of LOC, IOC and ROC in TOC (i.e., fLOC, fIOC, and fROC, respectively).

Measurements of soil microbial biomass and respiration

Using the freeze-stored soil samples, microbial biomass $\mathrm{C}$ (MBC) was measured by the fumigationextraction method. Briefly, $20 \mathrm{~g}$ of equivalent dry soil was exposed to chloroform vapor for $24 \mathrm{~h}$ and then extracted with $80 \mathrm{~mL}$ of $0.5 \mathrm{~mol} \mathrm{~L}{ }^{-1} \mathrm{~K}_{2} \mathrm{SO}_{4}$, shaken for $30 \mathrm{~min}$, and then filtered using Whatman filter paper no.42. Organic $\mathrm{C}$ concentration in the extracts was measured by a Multi 3100 N/C TOC/TON analyzer (Analytik Jena, Germany). MBC was calculated as the difference in extractable $\mathrm{C}$ before and after fumigation using a conversion factor of 0.45 (Vance et al. 1987). Microbial respiration (MR) was measured by determining $\mathrm{CO}_{2}$ evolution rates by incubating $25 \mathrm{~g}$ fresh soil at $60 \%$ water holding capacity at $25{ }^{\circ} \mathrm{C}$. $\mathrm{CO}_{2}$ was collected into $10 \mathrm{~mL}$ of $0.1 \mathrm{~mol} \mathrm{~L}^{-1} \mathrm{NaOH}$ solution and titrated with $0.05 \mathrm{~mol} \mathrm{~L}^{-1} \mathrm{HCl}$ after adding $1.0 \mathrm{~mol} \mathrm{~L}^{-1} \mathrm{BaCl}_{2}$ for precipitating carbonate at the incubation time of $10 \mathrm{~h}, 1,3,5$ and 7 days using the approach proposed by You et al. (2014). 
Measurements of soil enzyme activities

Two soil extracellular enzyme activities involved in degrading cellulose $(\beta-1,4$-glucosidase, BG, EC: 3.2.1.21) and chitin and peptidoglycan $(\beta-1,4-\mathrm{N}-$ acetyl-glucosaminidase, NAG, EC: 3.2.1.14), respectively, were measured. The activities of BG and NAG were determined on the basis of $p$-nitrophenol (PNP) released after cleavage of enzyme-specific synthetic substrates (You et al. 2014). In brief, the reaction mixture was composed of $0.2 \mathrm{~mL} 50 \mathrm{mM} p$-nitrophenyl- $\beta$-D-glucopyranoside and $0.2 \mathrm{~mL} 10 \mathrm{mM} p$ nitrophenyl-N-acetyl- $\beta$-D-glucosaminide with $0.8 \mathrm{~mL}$ of shaken and filtered soil slurry $(4 \mathrm{~g}$ fresh soil with $10 \mathrm{~mL} 50 \mathrm{mM}$ sodium acetate buffer, $\mathrm{pH}$ 5.0) incubated in a dark microcosm at $37^{\circ} \mathrm{C}$ for $1 \mathrm{~h}$. BG and NAG activities were measured with ultraviolet spectrophotometer at $410 \mathrm{~nm}$ after filtration, respectively. The total enzyme activities were expressed as $\mu \mathrm{mol} \mathrm{g}^{-1} \mathrm{~h}^{-1}$, on soil dry weight basis.

Calculation of microbial biomass-specific

respiration and carbon use efficiency

Based on the measurements of $\mathrm{MBC}$ and $\mathrm{MR}$, the microbial biomass-specific respiration $\left(\mathrm{qCO}_{2}\right)$ was calculated as (You et al. 2014):

$\mathrm{qCO}_{2}=\mathrm{MR} / \mathrm{MBC}\left(\mathrm{mg} \mathrm{CO} \mathrm{g}^{-1} \mathrm{C}_{\text {mic }}\right.$ day $\left.^{-1}\right)$.

Microbial $\mathrm{C}$ use efficiency based on $\mathrm{C}: \mathrm{N}$ stoichiometry $\left(\mathrm{CUE}_{\mathrm{C}: \mathrm{N}}\right)$ was calculated using the stoichiometric method proposed by Sinsabaugh et al. (2016) as:

$$
\begin{aligned}
\operatorname{CUE}_{\mathrm{C}: \mathrm{N}} & =\mathrm{CUE}_{\mathrm{MAX}}\left[\mathrm{S}_{\mathrm{C:N}} /\left(\mathrm{S}_{\mathrm{C}: \mathrm{N}}+\mathrm{K}_{\mathrm{C}}\right)\right], \text { where } \mathrm{S}_{\mathrm{C}: \mathrm{N}} \\
& =\left(1 / \mathrm{EEA}_{\mathrm{C}: \mathrm{N}}\right)\left(\mathrm{B}_{\mathrm{C}: \mathrm{N}} / \mathrm{L}_{\mathrm{C}: \mathrm{N}}\right),
\end{aligned}
$$

where $\mathrm{S}_{\mathrm{C}: \mathrm{N}}$ is a scalar that represents the extent to which the allocation of enzyme activities offsets the disparity between the elemental composition of available resources and the composition of microbial biomass; $K_{C}$ the half-saturation constant $\left(K_{C}=0.5\right)$; CUE $_{\text {MAX }}$ the upper limit for microbial growth efficiency based on thermodynamic constraints, $\mathrm{CUE}_{\mathrm{MAX}}=0.6$. EEA is the extracellular enzyme activity; $\mathrm{EEA}_{\mathrm{C}: \mathrm{N}}$ was calculated as the ratio of $\mathrm{BG}$ to NAG (i.e., BG/NAG), where $B G=\beta-1,4$-glucosidase and $\mathrm{NAG}=\beta-1,4-\mathrm{N}$-acetyl-glucosaminidase. Molar ratio of SOC to TN was used as estimates of $\mathrm{L}_{\mathrm{C}: \mathrm{N}}$.
Microbial biomass $\mathrm{C}: \mathrm{N}\left(\mathrm{B}_{\mathrm{C}: \mathrm{N}}\right)$ was also calculated as the molar ratio of microbial biomass $\mathrm{C}$ to $\mathrm{N}$. The $\mathrm{CUE}_{\mathrm{C}: \mathrm{N}}$ calculated here represents the communitylevel microbial CUE (Geyer et al. 2016).

Statistical analysis

A linear mixed-effects model was used to determine the effects of litter type treatments and $\mathrm{N}$ addition on physical and chemical fractions of SOC, MBC, MR, $\mathrm{qCO}_{2}, \mathrm{CUE}_{\mathrm{C}: \mathrm{N}}$ and enzyme activities. The litter type treatments and $\mathrm{N}$ addition, as well as the interaction between these two treatments were treated as fixed factors, and a plot nested within block term was treated as random factors. LSD test (least significant difference test) was used for post hoc multiple comparisons. The linear mixed-effects models were performed using the "lme4" package (Bates et al. 2014) in R 3.6.1 (R Development Core Team 2018). Prior to the analysis, the normality (Shapiro test) and the homoscedasticity of variance (Levene's test) of all variables were tested, and data were log-transformed for variables not conforming to normality. We also calculated the Cohen's $d$ index of effect sizes of litter type treatments and $\mathrm{N}$ addition on soil organic carbon fractions and microbial properties. Pairwise comparisons of SOC fractions and their relationships with microbial characteristics were determined using Pearson's correlation coefficient. Redundancy analysis (RDA) was used to analyze multivariate relationships between microbial characteristics and soil $\mathrm{C}$ and $\mathrm{N}$ properties. Forward selection ("ordistep" function) based on Monte Carlo tests with 999 permutations was used to identify key variables controlling microbial processes (i.e., $\mathrm{MBC}, \mathrm{MR}, \mathrm{CUE}_{\mathrm{C}: \mathrm{N}}$, and $\mathrm{qCO}_{2}$ ) using the package "Vegan" (Oksanen et al. 2016).

\section{Results}

\section{TOC and DOC}

Litter treatments had significant effects on the contents of TOC and DOC across all the three soil layers ( $p<0.05$; Fig. 1). The effects of $\mathrm{N}$ addition treatments were much weaker compared with the litter treatments, and were only significant for TOC in the top two soil layers (Fig. 2). There was no significant interactive effect between litter and $\mathrm{N}$ treatments on 


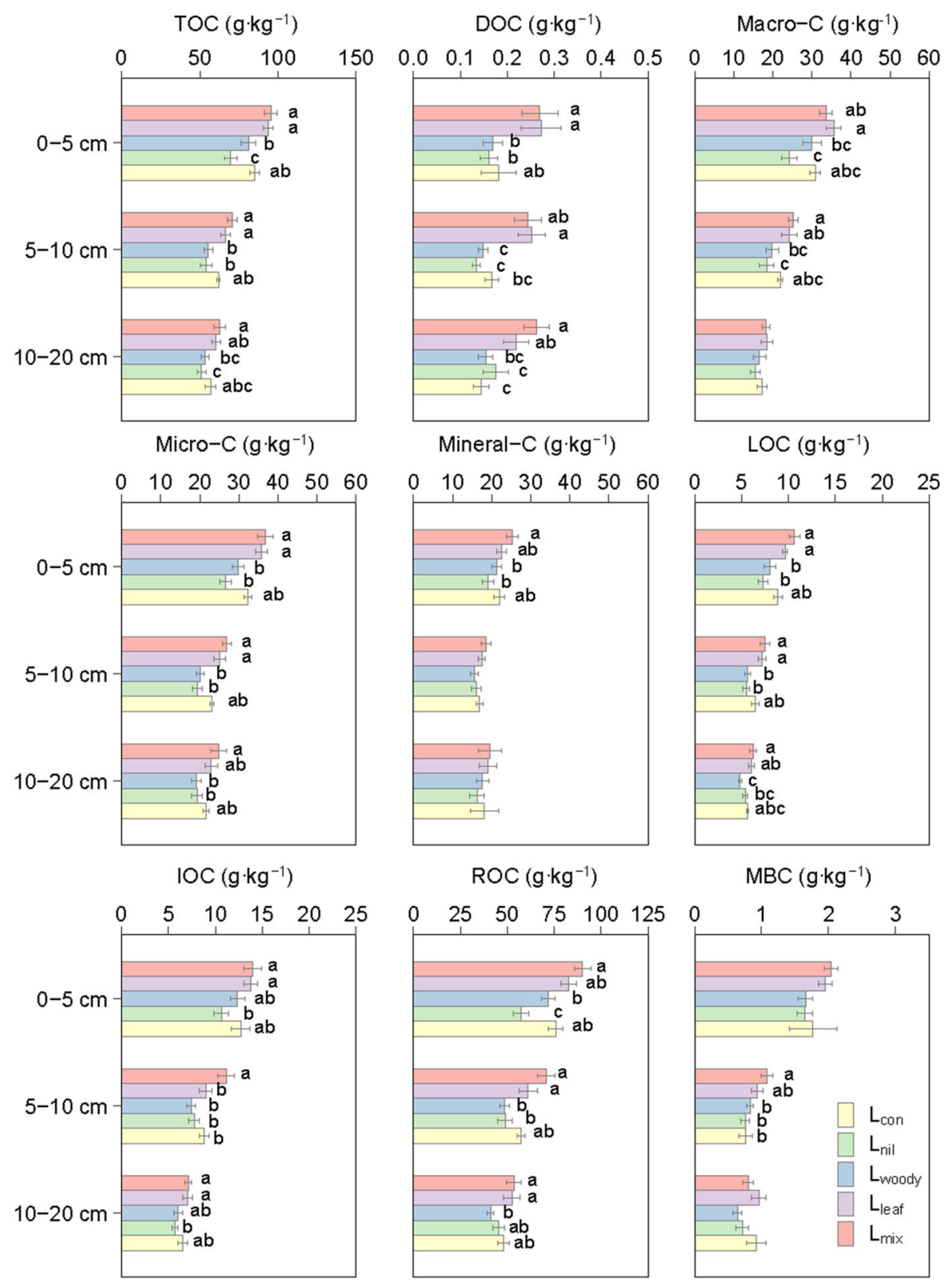

Fig. 1 Effects of litter manipulation on total soil organic carbon (TOC), dissolved organic carbon (DOC), three physical fractions and three chemical fractions of SOC, and microbial biomass carbon (MBC) in 0-5, 5-10 and 10-20 cm soil layers. Macro-C, soil organic carbon in the $250-2000 \mu \mathrm{m}$ soil aggregates; Micro-C, soil organic carbon in the 53-250 $\mu \mathrm{m}$ soil aggregates; Mineral-C, soil organic carbon in the $<53 \mu \mathrm{m}$ soil aggregates. $L O C$ labile organic carbon; IOC intermediate

TOC and DOC in any of the three soil layers $(p>0.05)$. An apparent phenomenon was that both TOC and DOC under $\mathrm{L}_{\text {nil }}$ and $\mathrm{L}_{\text {woody }}$ (treatments organic carbon; $R O C$ recalcitrant organic carbon. $L_{c o n}$ natural control soils; $L_{\text {nil }}$ complete removal of all aboveground litter; $L_{\text {woody }}$ placement of fine woody litter; $L_{\text {leaf }}$ placement of leaf litter; $L_{\text {mix }}$ placement of mixed leaf and fine woody litter. Error bars show one standard error. Different letters above the bar for the same soil layer indicate significant difference among treatments $(p<0.05)$

without leaf litter) were significantly lower than that under $\mathrm{L}_{\text {leaf }}$ and $\mathrm{L}_{\text {mix }}$ (treatments with leaf litter) in three soil layer depths (Fig. 1). However, both TOC 


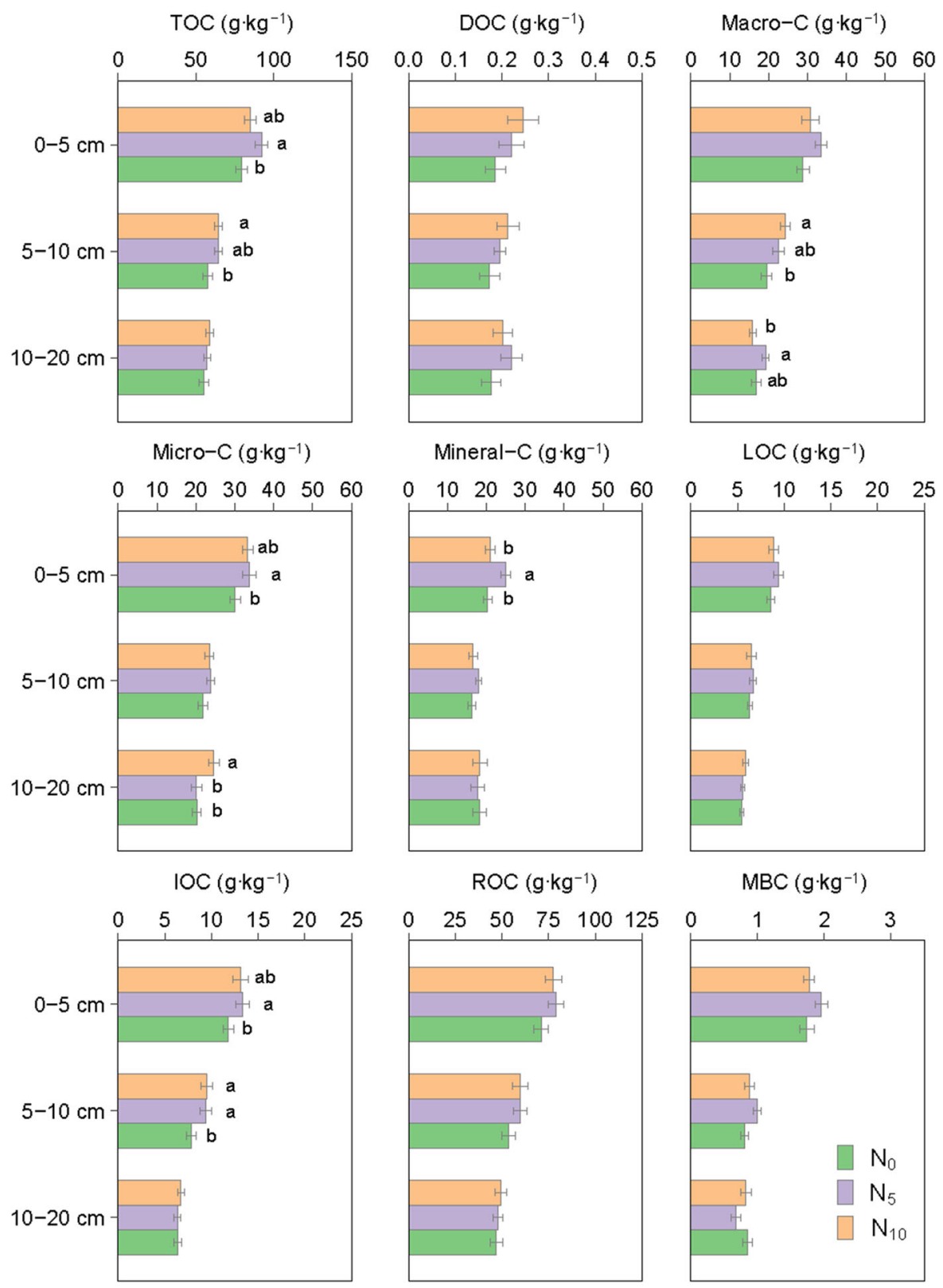

Fig. 2 Effects of nitrogen addition on TOC, DOC, Macro-C, Micro-C, Mineral-C, LOC, IOC, ROC and MBC in 0-5, 5-10 and $10-20 \mathrm{~cm}$ soil layers. $\mathrm{N}_{0}, 0 \mathrm{~g} \mathrm{~N} \mathrm{~m}^{-2}$ year $^{-1} ; \mathrm{N}_{5}$, $5 \mathrm{~g} \mathrm{~N} \mathrm{~m}^{-2}$ year $^{-1} ; \mathrm{N}_{10}, 10 \mathrm{~g} \mathrm{~N} \mathrm{~m}^{-2}$ year $^{-1}$ applied as urea.

and DOC did not significantly change under the four litter treatments compared to $\mathrm{L}_{\mathrm{con}}$ (Fig. 1) except that TOC under $\mathrm{L}_{\text {nil }}$ was significantly $17.9 \%$ lower in the $0-5 \mathrm{~cm}$ soil layer, DOC under $\mathrm{L}_{\text {leaf }}$ significantly $34.2 \%$ higher in the 5-10 soil layer, and DOC under $\mathrm{L}_{\text {leaf }}$ and $\mathrm{L}_{\text {mix }}$ significantly $34.4 \%$ and $45.3 \%$ higher in
Error bars show one standard error. Different letters above the bar for the same soil layer indicate significant difference among treatments $(p<0.05)$

the $10-20 \mathrm{~cm}$ soil layer, respectively. Moreover, the effect sizes of litter and $\mathrm{N}$ treatments on TOC and DOC were similar to that of the linear mixed-effects model in the three soil layers except that the TOC in the $0-5$ and $5-10 \mathrm{~cm}$ soil layers and DOC in the $5-10 \mathrm{~cm}$ soil layer were significant lower under $\mathrm{L}_{\mathrm{nil}}$ 
than under the $\mathrm{L}_{\text {con }}$ (Figs. S1-S3). $\mathrm{N}$ addition treatments resulted in significantly higher TOC under $\mathrm{N}_{5}$ in the $0-5 \mathrm{~cm}$ soil layer according to the effect size (Figs. S1-S3). The proportion of DOC in TOC, fDOC, in the $0-5 \mathrm{~cm}$ and $5-10 \mathrm{~cm}$ soil layers were significantly affected by litter treatments, with much lower fDOC under $\mathrm{L}_{\text {woody }}$ and $\mathrm{L}_{\text {nil }}$ compared with that under $\mathrm{L}_{\text {leaf }}(p<0.05$; Table S1). Significant interactions between litter and $\mathrm{N}$ treatments on fDOC occurred in the $0-5 \mathrm{~cm}$ and $10-20 \mathrm{~cm}$ soil layers, such that fDOC was much higher under $\mathrm{L}_{\text {leaf }}$ and $\mathrm{L}_{\text {mix }}$ than that under $\mathrm{L}_{\text {woody }}\left(p<0.05\right.$; Table $\mathrm{S} 1$ ). Compared to $\mathrm{L}_{\text {con }}$, none of the litter and $\mathrm{N}$ treatments significantly altered fDOC $(p>0.05$; Table S1).

Physical and chemical fractions of SOC

The effects of litter and $\mathrm{N}$ treatments on the contents of physical SOC fractions varied with the fraction types and differed among the soil layers. Significant interactions between the litter and $\mathrm{N}$ treatments were only observed for the Macro- $\mathrm{C}$ fractions in the $10-20 \mathrm{~cm}$ soil layer $(p<0.05$; Table S1). On average, the contents of all the three physical fractions (Macro-C, Micro-C, and Mineral-C) were greater under treatments with presence of leaf litter (i.e., $\mathrm{L}_{\text {leaf }}$, and $\mathrm{L}_{\text {mix }}$ ) than those without (i.e., $\mathrm{L}_{\text {nil }}$ and $\mathrm{L}_{\text {woody }}$ ), especially in the top 0-5 cm soil layer (Fig. 1). The contents of Macro-C and Micro-C in the $5-10 \mathrm{~cm}$ soil layer and Micro-C in the 10-20 cm soil layer were significantly greater under the litter treatments of $\mathrm{L}_{\text {leaf }}$ and $\mathrm{L}_{\text {mix }}$ than under $\mathrm{L}_{\text {nil }}$ and $\mathrm{L}_{\text {woody }}$. However, all the three physical SOC fractions under the four litter treatments did not show significant differences compared to that under $\mathrm{L}_{\text {con }}$ in all the three soil layers (Fig. 1). With consideration of the effect size, the Macro- $\mathrm{C}$ in the $0-5 \mathrm{~cm}$ soil layer and Micro-C in the $0-5$ and 5-10 cm soil layers under $\mathrm{L}_{\text {nil }}$ were significant lower compared to the $\mathrm{L}_{\mathrm{con}}$ (Figs. S1, S2). In terms of the relative changes to $\mathrm{L}_{\text {con }}$, they ranged from - 28 to $14 \%$ for all treatments and in all soil layers.

$\mathrm{N}$ addition treatments significantly affected the contents of Micro-C and Mineral-C in the $0-5 \mathrm{~cm}$ soil layer, Macro-C in the 5-10 cm soil layer, and Macro$\mathrm{C}$ and Micro-C in the $10-20 \mathrm{~cm}$ soil layer (Fig. 2), which were consistent with the results of the effect sizes (Figs. S1-S3). The contents of the three physical fractions were not significantly different between $\mathrm{N}_{5}$ and $\mathrm{N}_{10}$. Litter treatments had no significant effects on
fMacroC, fMicroC and fMineralC in all the three soil layers (Fig. S7); whilst $\mathrm{N}$ addition treatments significantly affected fMacro-C and fMicro-C in the 10-20 cm soil layer (Fig. S8). On average, 36\%, $38 \%$ and $26 \%$ of SOC were stored in Macro-, Micro-, and Mineral-aggregates in the $0-5 \mathrm{~cm}$ soil layer respectively, and $35 \%, 37 \%$ and $28 \%$ in the $5-10 \mathrm{~cm}$ soil layer respectively, and $31 \%, 38 \%$ and $31 \%$ in the $10-20 \mathrm{~cm}$ soil layer respectively.

The contents of chemical SOC fractions (i.e., LOC, IOC and ROC) were significantly affected by litter treatments in all soil layers (Fig. 1). The effects of litter treatments on the chemical SOC fractions were similar to their effects on physical SOC fractions. Notably, the three chemical SOC fractions were all significantly greater under $\mathrm{L}_{\text {mix }}$ than under $\mathrm{L}_{\text {nil }}$ (Fig. 1). Compared to $\mathrm{L}_{\text {con }}$, IOC under the $\mathrm{L}_{\text {mix }}$ was significantly $21.0 \%$ greater in the $5-10 \mathrm{~cm}$ soil layer and ROC under the $\mathrm{L}_{\text {nil }}$ significantly $24.2 \%$ smaller in the $0-5 \mathrm{~cm}$ soil layer (Fig. 1). The size analysis also showed the LOC in the $0-5 \mathrm{~cm}$ soil layer, IOC in the $10-20 \mathrm{~cm}$ soil layer and ROC in the $0-5$ and $5-10 \mathrm{~cm}$ soil layers were significantly higher under $\mathrm{L}_{\text {mix }}$ than that under $\mathrm{L}_{\text {con }}$ (Figs. S1-S3). The effect of $\mathrm{N}$ addition treatments was only significant on the content of IOC in the $0-5 \mathrm{~cm}$ and $5-10 \mathrm{~cm}$ soil layers (Fig. 2). Significant interactive effects between litter and $\mathrm{N}$ treatments were observed on LOC and ROC in the 10-20 cm soil layer (Table S1). In terms of the relative quantity $(\%)$ of the chemical fractions, they were not significantly affected by the litter and $\mathrm{N}$ treatments. Consistently, ROC accounted for the majority $(>78 \%)$ of the SOC in the three soil layers.

Microbial biomass, respiration, carbon use efficiency and enzymatic activities

Overall, the treatment responses of the microbial characteristics investigated (i.e., $\mathrm{MBC}, \mathrm{CUE}_{\mathrm{C}: \mathrm{N}}$ and $\mathrm{qCO}_{2}$ ) were mostly insignificant across three soil layers except for microbial respiration (i.e., MR). Only $\mathrm{MBC}$ in the $5-10 \mathrm{~cm}$ soil layer was significantly greater under $\mathrm{L}_{\text {mix }}$ than under $\mathrm{L}_{\text {con }}, \mathrm{L}_{\text {nil }}$ and $\mathrm{L}_{\text {woody }}$ (Fig. 1). A significant interactive effect between litter and $\mathrm{N}$ treatments on MR occurred in the $0-5 \mathrm{~cm}$ soil layer (Table S1). While the effects of litter treatments on MR were significant in all three layers (Fig. 3), the effects of $\mathrm{N}$ addition treatments were only significant in the $0-5 \mathrm{~cm}$ and $5-10 \mathrm{~cm}$ soil layers (Fig. 4). MR 


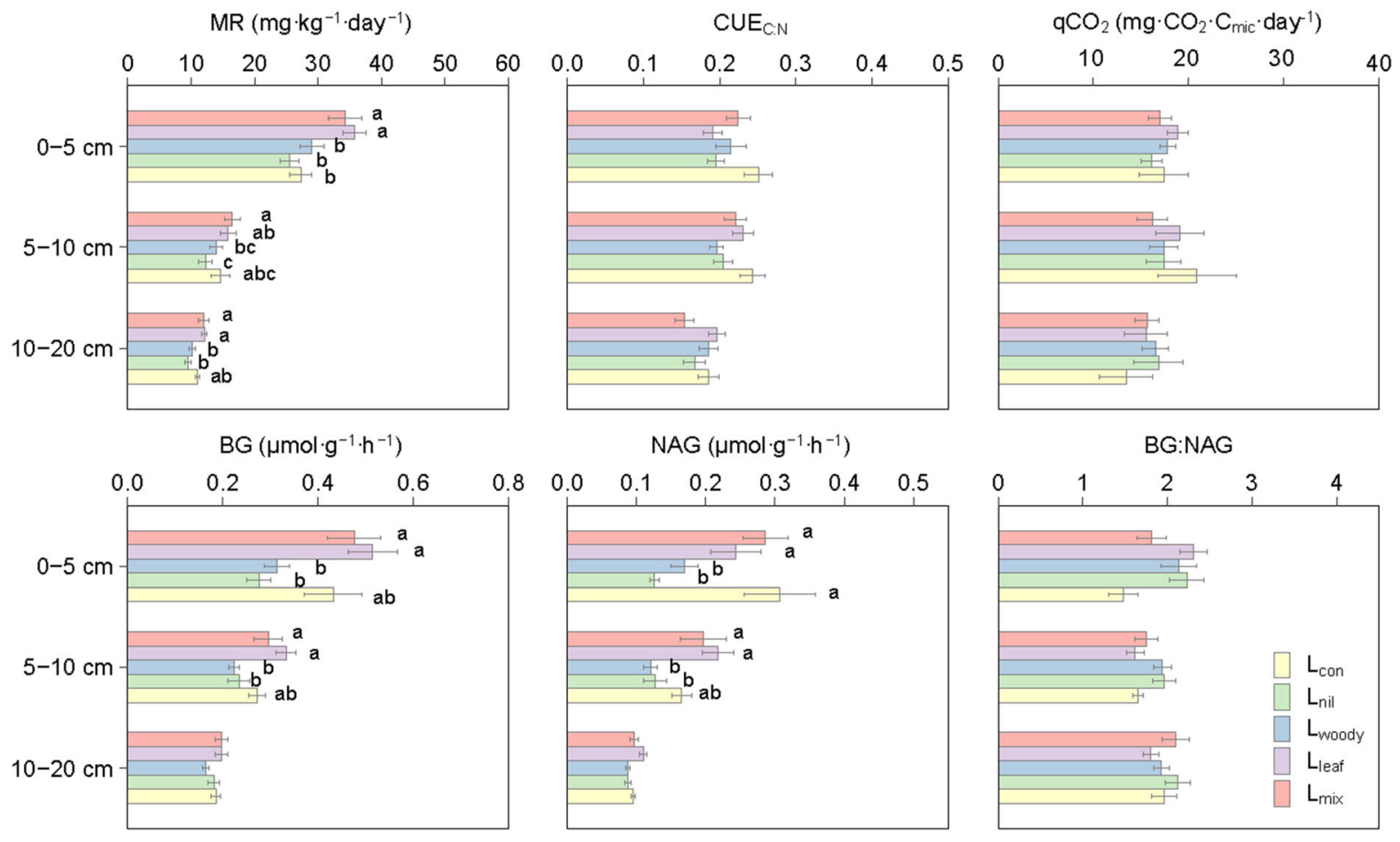

Fig. 3 Effects of litter manipulation on soil microbial properties (i.e., $\mathrm{MR}, \mathrm{CUE}_{\mathrm{C}: \mathrm{N}}, \mathrm{qCO}_{2} \mathrm{BG}, \mathrm{NAG}$ and $\mathrm{BG}: \mathrm{NAG}$ ) in $0-5,5-10$ and $10-20 \mathrm{~cm}$ soil layers. MR, microbial respiration; $\mathrm{CUE}_{\mathrm{C}: \mathrm{N}}$, carbon use efficiency; $\mathrm{qCO}_{2}$, microbial

was $20.3 \%$ and $23.5 \%$ greater $(p<0.05)$ under $\mathrm{L}_{\text {mix }}$ and $\mathrm{L}_{\text {leaf }}$, respectively, than under $\mathrm{L}_{\mathrm{con}}$ in the $0-5 \mathrm{~cm}$ soil layer (Fig. 3). There was no significant effect of litter treatments on $\mathrm{CUE}_{\mathrm{C}: \mathrm{N}}$ and $\mathrm{qCO}_{2}$ in any of the three soil layers ( $p>0.05$, Fig. 3$)$. In consideration of the effect size, however, $\mathrm{CUE}_{\mathrm{C}: \mathrm{N}}$ under $\mathrm{L}_{\text {leaf }}$ in the $0-5 \mathrm{~cm}$ soil layer and under $\mathrm{L}_{\text {nil }}$ and $\mathrm{L}_{\text {woody }}$ in the $5-10 \mathrm{~cm}$ soil layer were significant lower that that under $\mathrm{L}_{\text {con }}$ (Figs. S4, S5). The activities of two extracellular enzymes-BG and NAG - were significantly greater under $\mathrm{L}_{\text {leaf }}$ and $\mathrm{L}_{\text {mix }}$ than under $\mathrm{L}_{\text {nil }}$ and $\mathrm{L}_{\text {woody }}$ in the $0-5 \mathrm{~cm}$ and 5-10 cm soil layers (Fig. 3). NAG was $44.6 \%$ and $59.0 \%$ lower under $\mathrm{L}_{\text {woody }}$ and $\mathrm{L}_{\text {nil }}$, respectively, than under $\mathrm{L}_{\mathrm{con}}$ in the $0-5 \mathrm{~cm}$ soil layer. The effects of $\mathrm{N}$ addition treatments and its interaction with litter treatment on enzyme activities, $\mathrm{CUE}_{\mathrm{C}: \mathrm{N}}$ and $\mathrm{qCO}_{2}$ were insignificant in the three soil layers ( $p>0.05$; Fig. 4$)$. The ratio of BG to NAG exhibited no significant response to litter and $\mathrm{N}$ treatments in all soil layers except for the effects of $\mathrm{N}$ addition in the 10-20 cm soil layer (Figs. 3 and 4). However, the ratio of BG to NAG was significantly metabolic quotient; BG, $\beta$-1,4-glucosidase; NAG, $\beta-1,4-\mathrm{N}$ acetyl-glucosaminidase. Error bars show one standard error. Different letters above the bar for the same soil layer indicate significant difference among treatments $(p<0.05)$

higher under $\mathrm{L}_{\text {nil }}, \mathrm{L}_{\text {woody }}$ and $\mathrm{L}_{\text {leaf }}$ in the $0-5 \mathrm{~cm}$ soil layer and under $\mathrm{L}_{\mathrm{nil}}$ and $\mathrm{L}_{\text {woody }}$ in the $5-10 \mathrm{~cm}$ soil layer than under the $\mathrm{L}_{\text {con }}$, and significant lower in the $10-20 \mathrm{~cm}$ soil layer under $\mathrm{N}_{10}$ than under $\mathrm{N}_{0}$, based on the assessment by effect size (Figs. S4-S6).

The association of microbial properties with SOC compositions and nutrient status

MBC, MBN and MR were all positively correlated with soil physical and chemical SOC fractions in the 0-5 cm and 5-10 cm soil layers (Fig. 5). There were significant negative correlations of $\mathrm{MBC}$ and MBN with fIOC in the $0-5 \mathrm{~cm}$ soil layer and between MR and fMineral-C in the 5-10 cm soil layer. $\mathrm{CUE}_{\mathrm{C}: \mathrm{N}}$ was not significantly correlated with either SOC fractions or the $\mathrm{N}$ addition level in all three soil layers (Fig. 5). $\mathrm{qCO}_{2}$ was positively correlated with DOC, DOC/TOC and DON in the $0-5 \mathrm{~cm}$ soil layer and with $\mathrm{NO}_{3}{ }^{-}-\mathrm{N}$ and fROC in 10-20 cm soil layer (Fig. 5).

According to the RDA, in the $0-5 \mathrm{~cm}$ soil layer, the assessed seven SOC component fractions and $\mathrm{N}$ 


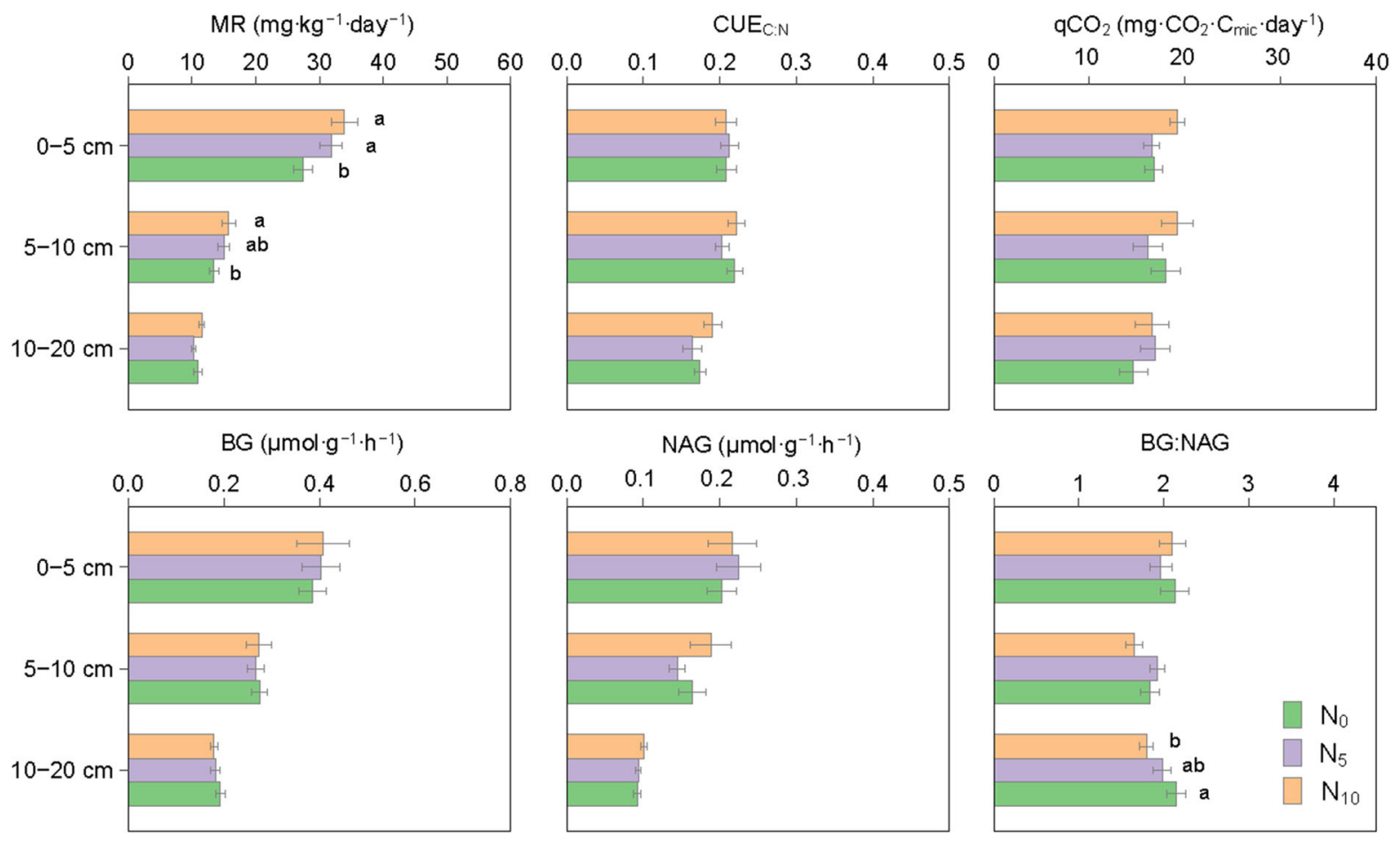

Fig. 4 Effects of nitrogen addition on soil microbial properties (i.e., MR, $\mathrm{CUE}_{\mathrm{C}: \mathrm{N}}, \mathrm{qCO}_{2} \mathrm{BG}, \mathrm{NAG}$ and BG:NAG) in 0-5, 5-10 and $10-20 \mathrm{~cm}$ soil layers. Error bars show one standard error.

addition level accounted for $61 \%$ of the total variance in $\mathrm{MBC}, \mathrm{MR}, \mathrm{CUE}_{\mathrm{C}: \mathrm{N}}$ and $\mathrm{qCO}_{2}$ (Fig. S9). Particularly, RDA identified that LOC, DON and DOC/TOC were the strongest predictors for $\mathrm{MBC}, \mathrm{MR}$, and $\mathrm{qCO}_{2}$, respectively (Fig. 6). In the 5-10 cm soil layer, RDA explained $49 \%$ of the variance in microbial properties investigated (Fig. S9); TN and DOC were the most influential variables on $\mathrm{MBC}$ and $\mathrm{MR}$, respectively (Fig. 6). In the $10-20 \mathrm{~cm}$ soil layer, $57 \%$ of the total variation in microbial characteristics was explained by the RDA (Fig. S9); and $\mathrm{NH}_{4}{ }^{+}-\mathrm{N}, \mathrm{IOC}$ and $\mathrm{NO}_{3}{ }^{-}-\mathrm{N}$ were the most important variables affecting $\mathrm{MBC}, \mathrm{MR}$ and $\mathrm{qCO}_{2}$ (Fig. 6). Specifically, $\mathrm{MBC}, \mathrm{MR}$ and $\mathrm{qCO}_{2}$ were significantly and positively correlated with the most critical predictors identified in three soil layers.

\section{Discussion}

Effects of litter treatments on SOC fractions

Inconsistent with our first hypothesis, we found that the litter type alone played a predominant role in
Significant differences in the same soil layer are denoted by different letters $(p<0.05)$

controlling the content in different fractions of SOC. Changes in SOC were mainly related to the litter inputs of relatively high quality (i.e., leaves in this study) rather than the quantity. There were three lines of evidence. First, almost all physical and chemical C fractions were significantly higher under $\mathrm{L}_{\text {leaf }}$ and $\mathrm{L}_{\text {mix }}$ (the treatments with leaves) than under $\mathrm{L}_{\text {woody }}$ (the treatment without leaves). Secondly, there were no significant differences between $\mathrm{L}_{\text {leaf }}$ and $\mathrm{L}_{\text {mix }}$ in the total SOC and its composition. As the main difference between $\mathrm{L}_{\text {leaf }}$ and $\mathrm{L}_{\text {mix }}$ is that $\mathrm{L}_{\text {leaf }}$ includes leaf litter only, while $\mathrm{L}_{\text {mix }}$ includes woody and leaf litter, the similar effects of $\mathrm{L}_{\text {leaf }}$ and $\mathrm{L}_{\text {mix }}$ on SOC and its composition indicate that woody component has very limited influence after eight years of treatment. Thirdly and more directly, total SOC and its composition were comparable between $\mathrm{L}_{\text {nil }}$ (the treatment without any forest-floor litter input) and $\mathrm{L}_{\text {woody }}$, suggesting that woody litter does not significantly contribute to the SOC pool, at least in the duration of eight years in our study.

This dominant effect of litter quality may attribute to that the decomposer community preferentially 


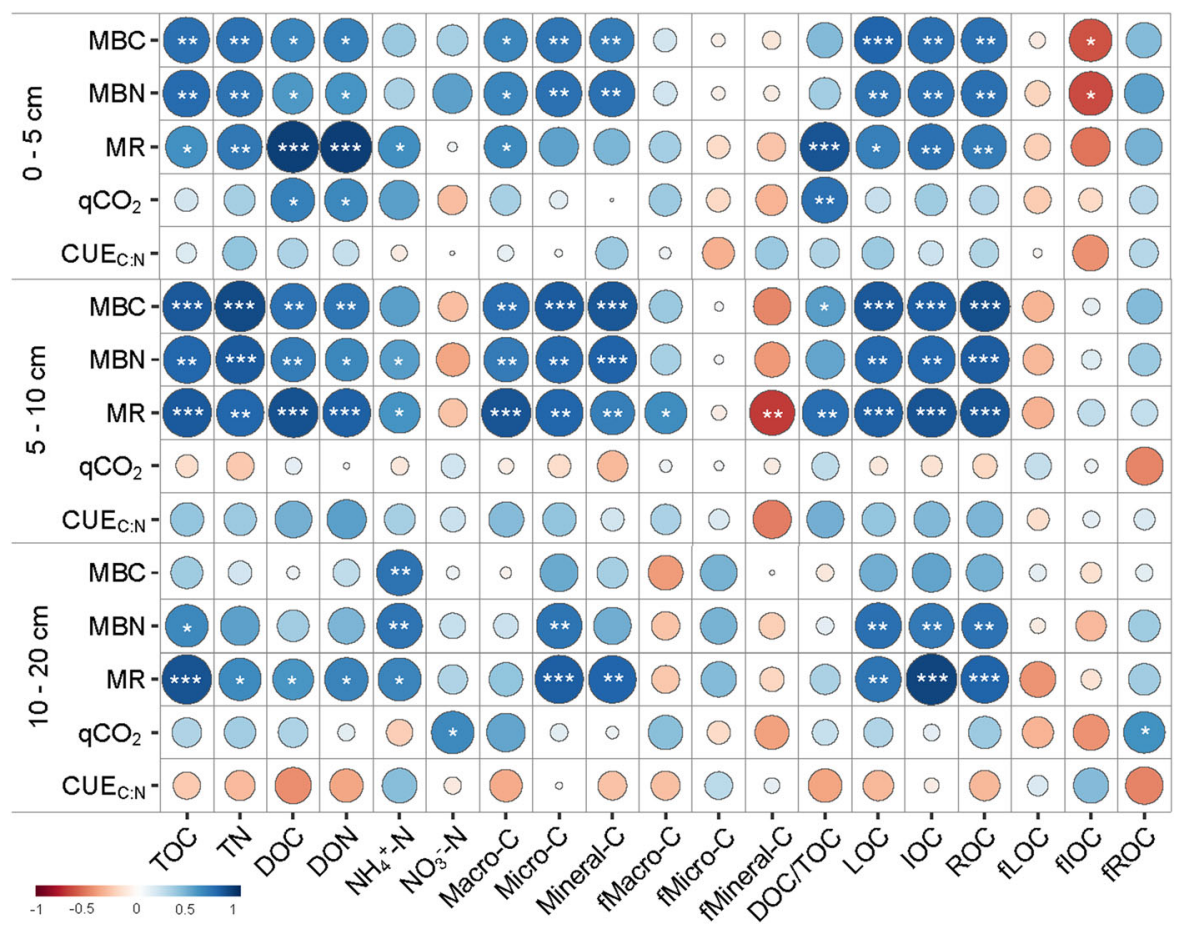

Fig. 5 Pearson's correlation coefficients matrix between soil microbial properties and SOC composition and nutrient status is displayed with a color gradient in $0-5 \mathrm{~cm}, 5-10 \mathrm{~cm}$ and $10-20 \mathrm{~cm}$ soil layers. Blue indicates positive correlation; red indicates the negative correlation. The darker the color, the greater the correlation. fMacro-C, the proportion of OC in the 250-2000 $\mu \mathrm{m}$ soil aggregates; fMicro-C, the proportion of OC

fragment/decay high-quality litter (Hättenschwiler et al. 2005), resulting in quick evolution of highquality litter to small particles including microbial debris, which again are easier to be translocated to the mineral soil (Moorhead and Sinsabaugh 2006). In addition, high-quality litter contains a large fraction of dissolvable organic materials which directly contribute to mineral SOC pool through percolating water (Kalbitz et al. 2000). Indeed, this point was supported by the significantly higher DOC under $\mathrm{L}_{\text {leaf }}$ and $\mathrm{L}_{\text {mix }}$ (Fig. 1). Despite that $\mathrm{L}_{\text {leaf }}$ and $\mathrm{L}_{\text {mix }}$ significantly increased the soil physical and chemical $\mathrm{C}$ fractions compared with $\mathrm{L}_{\text {nil }}$, no significant differences were found compared with $\mathrm{L}_{\text {con }}$ (Fig. 1), which may be due to soil priming induced under $\mathrm{L}_{\text {leaf }}$ and $\mathrm{L}_{\text {mix }}$ that compensates for new inputs of organic C (Lajtha et al. 2018; Sayer et al. 2011). Indeed, $\mathrm{L}_{\text {leaf }}$ and $\mathrm{L}_{\text {mix }}$ resulted in significantly higher enzyme activities and microbial respiration than $\mathrm{L}_{\text {woody }}$ and $\mathrm{L}_{\text {nil }}$ in the $0-5$ and $5-10 \mathrm{~cm}$ soil layers (Fig. 3), which implies the in the 53-250 $\mu \mathrm{m}$ soil aggregates; fMineral-C, the proportion of OC in the $<53 \mu \mathrm{m}$ soil aggregates. fLOC, the proportion of labile organic carbon; fIOC, the proportion of intermediate organic carbon; fROC, the proportion of recalcitrant organic carbon. The asterisk denotes the statistical significance: $* p<0.05, * * p<0.01, * * * p<0.001$. (Color figure online)

existence of the positive priming effects (Sayer et al. 2011; Cotrufo et al. 2013).

\section{Effects of $\mathrm{N}$ addition on SOC fractions}

Compared with the general significant main effects of litter treatment on all SOC fractions in all soil layers, the effects of $\mathrm{N}$ addition were relatively limited. We only detected significant effects of $\mathrm{N}$ addition treatment on total SOC and several specific SOC fractions in selective soil layers. For example, $\mathrm{N}$ addition treatments significantly increased total SOC in the $0-5$ and 5-10 cm soil layers (Fig. 2). A major reason could be that many temperate forests are N-limited (Nadelhoffer et al. 1999), which resulted in limited or no change in the formation and transformation of SOC with additional $\mathrm{N}$ inputs. This is also supported by the results of microbial enzyme activity involved in $\mathrm{N}$ acquisition. That is, $\mathrm{N}$ addition did not significantly affect the activity of NAG in all three soil layers in this 

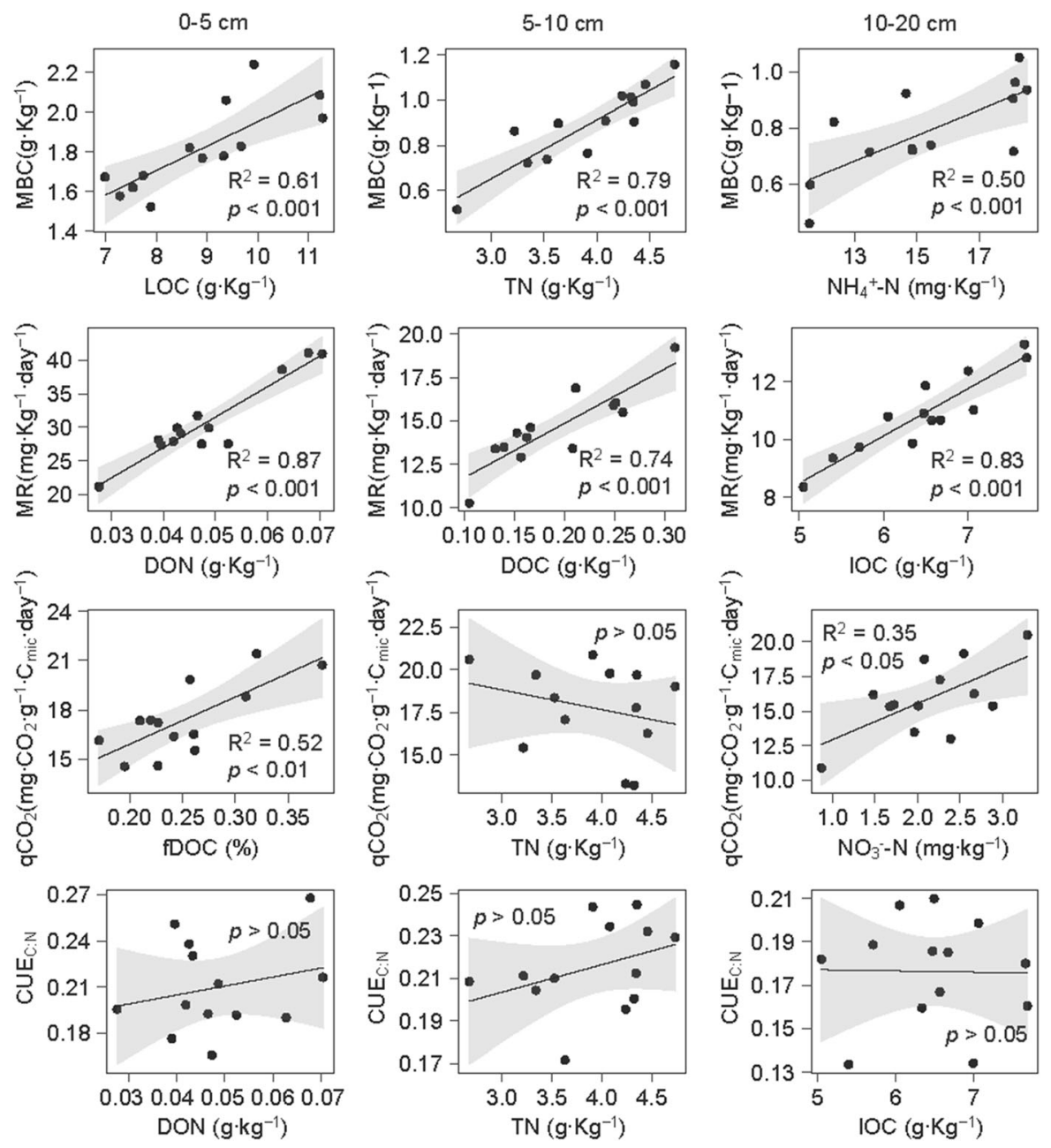

Fig. 6 The relationship between microbial properties (i.e., $\mathrm{MBC}, \mathrm{MR}, \mathrm{CUE}_{\mathrm{C}: \mathrm{N}}$, and $\mathrm{qCO}_{2}$ ) and their corresponding most important predictors identified by redundancy analysis (RDA) in

study (Fig. 4). Previous investigations in this experiment also found that the activities of BG, NAG, phenol oxidase and peroxidase were not affected by five years of $\mathrm{N}$ addition in the $0-5 \mathrm{~cm}$ soil layer (Sun et al. 2016).

Janssens et al. (2010) had proposed two, mutually non-exclusive, mechanisms to explain the $\mathrm{N}$-induced response of SOC cycling: (1) enhanced chemical stabilization of organic $\mathrm{C}$ into recalcitrant compounds which are resistant to microbial decay; and (2) preferential utilization of labile, energy-rich compounds by microbes, but retarded decomposition of recalcitrant compounds. Based on our data, nonetheless, we did not find solid evidence to support these two hypotheses because none of the three chemical the $0-5 \mathrm{~cm}, 5-10 \mathrm{~cm}$ and $10-20 \mathrm{~cm}$ soil layers. $T N$ total nitrogen; DOC, DON dissolved organic carbon and nitrogen

fractions showed significant difference among the $\mathrm{N}$ addition levels except for IOC in the $0-5$ and 5-10 cm soil layers (Fig. 2). Due to the slow formation of recalcitrant SOC compounds or saturation of mineral binding capacity, longer term experiment is required to detect changes in recalcitrant SOC pools to verify the two hypotheses. Moreover, Craine et al. (2007) found that microbes use labile substrates to acquire $\mathrm{N}$ from recalcitrant organic matter under low $\mathrm{N}$ availability and this "microbial nitrogen mining" is consistently suppressed by high soil $\mathrm{N}$ supply or substrate $\mathrm{N}$ concentrations. Lack of apparent treatment effects by $\mathrm{N}$ addition in this study could result from the possible resilience of the soil and microbial 
communities to the relatively low level of $\mathrm{N}$ addition rate applied.

Different responses of physical and chemical fractions to litter and $\mathrm{N}$ treatments

The physical protection of SOC from decomposition (e.g. SOC bonds with silt and clay aggregates to form organic-mineral complex) and the chemical decomposability of SOC components are two important mechanisms underpinning SOC stabilization (Schmidt et al. 2011; Hemingway et al. 2019). In this study, litter treatment did not significantly increase the mineralbound organic $\mathrm{C}$ fractions (fMineral-C) in different soil layers (Fig. S7), but the $\mathrm{L}_{\text {woody }}$ and $\mathrm{L}_{\text {mix }}$ (the treatments with woody litter) significantly increased fROC compared with $\mathrm{L}_{\text {nil }}$ in the $0-5 \mathrm{~cm}$ soil layer (Fig. S7). It is likely that the input of relatively recalcitrant woody litter significantly increased the proportion of chemically stable carbon components (e.g. lignin), and played a small role in regulating physical protection of SOC. However, all the four litter treatments did not significantly change fROC compared to $\mathrm{L}_{\text {con }}$ (Fig. S7), suggesting the weak influence of woody litter on SOC fractions. The very slow incorporation of woody litter to the mineral soil is likely the underlying reason for such insignificant effects even after eight years of experiment.

$\mathrm{N}$ addition treatments only had significant effects on one of the three chemical fractions (i.e., IOC) in the $0-5 \mathrm{~cm}$ and $5-10 \mathrm{~cm}$ soil layers, and its effect on the three physical SOC fractions were layer-dependent (Fig. 2). This result may be explained by $\mathrm{N}$-induced changes in root growth and associated microbial processes (e.g. fungal hyphae), which are two main biotic factors regulating the formation and stability of soil aggregates (Miller and Jastrow 2000). For the formation and turnover of soil aggregates, most studies focused on agricultural soils (Six and Lenders 2000). Few studies have assessed the potential changes of soil aggregation processes under the change of litter and $\mathrm{N}$ inputs and the relevant consequences on SOC dynamics in natural ecosystems such as temperate forests. As SOC in different soil aggregates exhibits distinct turnover behaviors (von Lützow et al. 2007), the observed significant effects of $\mathrm{N}$ addition treatments on SOC in different aggregates offer an alternative mechanism to explain the observed differential changes in SOC and its physical and chemical composition under $\mathrm{N}$ deposition.

Effects of litter and $\mathrm{N}$ treatments on soil microbial metabolism

There were significant positive correlations between SOC fractions (e.g., TOC, TN, DOC and DON) and microbial properties (e.g., $\mathrm{MBC}, \mathrm{MBN}$ and $\mathrm{MR}$ ) (Fig. 5), indicating the litter input may increase the microbial C substrate availability. Meta-analysis also found that litter inputs had a strong positive impact on soil respiration, labile $\mathrm{C}$ availability, and the abundance of soil microorganisms (Zhang et al. 2020). However, contrary to our second hypothesis that microbes adjust substrate utilization strategies under $\mathrm{N}$ addition and litter manipulation treatments, we found that microbial substrate utilization strategies are relatively persistent under the given treatments in this study. The two measures of microbial $\mathrm{C}$ use efficiency (i.e., $\mathrm{CUE}_{\mathrm{C}: \mathrm{N}}$ and $\mathrm{qCO}_{2}$ ) did not show significant response to either litter or $\mathrm{N}$ treatments (Figs. 3 and 4), albeit that the microbial respiration had been significantly affected by litter treatments in all soil layers (Fig. 3). In addition, the correlation analysis also showed that the magnitude of the correlation of $\mathrm{CUE}_{\mathrm{C}: \mathrm{N}}$ and $\mathrm{qCO}_{2}$ with variables reflecting soil substrate and nutrient status was lower than the magnitude of the correlation of $\mathrm{CUE}_{\mathrm{C}: \mathrm{N}}$ and $\mathrm{qCO}_{2}$ with microbial biomass and respiration (Fig. 5). These results may suggest that the energy and nutrient in the top $20 \mathrm{~cm}$ mineral soil layer at the studied site are not strong regulators and/or limiting factors of microbes; therefore microbes do not need to significantly adjust their functional properties such as $\mathrm{C}$ use efficiency (van Groenigen et al. 2013).

Several mechanisms may explain why microbial substrate utilization was unaffected by the imposed changes in $\mathrm{N}$ availability and litter inputs. Firstly, most energy and nutrient sources are inaccessible for microbes in the bulk soil environment (Schmidt et al. 2011). A number of studies have demonstrated that the accessibility of SOC (i.e., substrate availability) by microbes is the limiting factor of soil organic matter decomposition (Cotrufo et al. 2013; Dungait et al. 2012). For this reason, microbial activity and function would be determined by substrates that are readily available, which are also determined by the soil physical environment (e.g., microbial substrate 
availability regulated by changes in soil temperature and moisture). Rather, both $\mathrm{N}$ addition treatments and litter manipulation in this study may have limited effects on the physical accessibility of SOC to microorganisms (Moinet et al. 2018). On the one hand, the added $\mathrm{N}$ may leave the system quickly due to the volatility of urea (Ramirez et al. 2010). On the other hand, as discussed above, the studied forest is not $\mathrm{N}$-limited. In addition, more time may be required to degrade the added litter (especially woody litter) before microbial utilization. Secondly, microbial activity and substrate use efficiency would be limited by other environmental factors rather than substrate availability. For example, the effect of substrate availability on $\mathrm{CUE}_{\mathrm{C}: \mathrm{N}}$ depends on the availability of other nutrients (e.g. phosphorus) and the elemental stoichiometry (Hessen et al. 2004; Sinsabaugh et al. 2013).

Soil moisture and temperature are also important environmental factors regulating microbial metabolism (Manzoni et al. 2012). In this study, compared with $\mathrm{L}_{\text {nil }}$ and $\mathrm{L}_{\text {con }}$, increased litter cover (i.e., $\mathrm{L}_{\text {mix }}$ ) significantly increased soil mass water content $(p<0.05)$; and there were also significant differences in soil temperature under the litter treatments $(p<0.001$; Table S1). Meanwhile, all microbial properties were measured based on soil cores sampled at a particular point in time. As such, the measured microbial properties may only reflect the behavior of microbes at that particular time; while litter and $\mathrm{N}$ addition usually have a transient effect on microbial substrate use efficiency (Poeplau et al. 2019). It is important to monitor temporal dynamics of microbial processes in order to explicitly quantify the association of microbial properties with nutrient and energy availability.

Extracellular enzymes play a critical role in breaking down polymers into smaller molecules that can be directly used by microbes (Carreiro et al. 2000). Results in this study suggested that the two extracellular enzymes degrading cellulose (BG) and chitin and peptidoglycan (NAG) had significantly greater activities under $\mathrm{L}_{\text {leaf }}$ and $\mathrm{L}_{\text {mix }}$ than under $\mathrm{L}_{\text {nil }}$ and $\mathrm{L}_{\text {woody }}$ (Figs. 3 and S3-S6). It is especially important to note that their changes are nearly synchronous, i.e., the BG/ NAG ratio was relatively constant under the litter and $\mathrm{N}$ treatments (Figs. 3 and 4). As two enzymes specifically metabolize different substrates (i.e., BG for $\mathrm{C}$ and NAG for $\mathrm{N}$ ), the rate of increase in the activity of one enzyme would override the rate of increase in the activity of the other if microbes are limited by $\mathrm{C}$ ( or $\mathrm{N}$ ). Their synchronous responses provide further evidence that litter manipulation and $\mathrm{N}$ addition do not shift the substrate (C) utilization strategy of microbes.

\section{Conclusions}

After 8 years of litter and $\mathrm{N}$ addition treatments in a mixed pine-oak forest under temperate climate, we found significant changes in SOC content including DOC and various physical and chemical component fractions. This change was predominantly controlled by the quality of carbon inputs represented by woody materials and leaves in this study. Compared to the control, however, the removal of forest-floor litter or increased inputs did not significantly affect the content in various SOC fractions after eight years, which might be due to reduced and stimulated decomposition under litter removal and input, respectively, resulting from soil priming. In order to quantify the contribution of aboveground litter components to mineral SOC pool, we strongly recommend that the dynamics of aboveground litter derived $\mathrm{C}$ pool and root-derived $\mathrm{C}$ should be properly traced (e.g. using $\mathrm{C}$ isotopes) and linked with the dynamics of mineral SOC pool. $\mathrm{N}$ input (i.e., in the form of urea in this study) could not compensate the effect of litter quality, as demonstrated by the general insignificant effect of either $\mathrm{N}$ addition or its interaction with litter input. This may be due to that the fertilization effect of $\mathrm{N}$ addition was weak or the urea- $\mathrm{N}$ addition leaves the system quickly via various pathways (e.g., leaching and volatilization). Although significant changes occurred in SOC fractions, microbial substrate utilization was relatively resistant to litter manipulation and $\mathrm{N}$ addition treatments in this study. Overall, our study demonstrates that litter quality change is a more significant regulator of SOC dynamics than litter quantity and soil $\mathrm{N}$ availability in this temperate forest.

Acknowledgements This work was financially supported by the National Natural Science Foundation of China (Grant Nos. 31870426, 31470623). We thank Hua Su, Zhiyong Zhou, Xiao Zhang, and Daiyang Zhou for their assistance in the field sampling and laboratory analysis. 
Open Access This article is licensed under a Creative Commons Attribution 4.0 International License, which permits use, sharing, adaptation, distribution and reproduction in any medium or format, as long as you give appropriate credit to the original author(s) and the source, provide a link to the Creative Commons licence, and indicate if changes were made. The images or other third party material in this article are included in the article's Creative Commons licence, unless indicated otherwise in a credit line to the material. If material is not included in the article's Creative Commons licence and your intended use is not permitted by statutory regulation or exceeds the permitted use, you will need to obtain permission directly from the copyright holder. To view a copy of this licence, visit http://creativecommons.org/licenses/by/4.0/.

Author contributions OJS designed the field experiment. OJS and $\mathrm{ZL}$ conceived the study and interpreted the results. XG conducted measurements, performed field sampling and data analyses, and prepared the initial draft of the manuscript. ZL and OJS substantially revised the manuscript.

\section{References}

Bates D, Mächler M, Bolker B, Walker S (2014) Fitting linear mixed-effects models using lme4. arXivpreprintarXiv: 1406.5823

Carreiro MM, Sinsabaugh RL, Repert DA, Parkhurst DF (2000) Microbial enzyme shifts explain litter decay responses to simulated nitrogen deposition. Ecology 81(9):2359-2365. https://doi.org/10.1890/0012-9658(2000)081[2359: MESELD]2.0.CO;2

Castellano MJ, Mueller KE, Olk DC, Sawyer JE, Six J (2015) Integrating plant litter quality, soil organic matter stabilization, and the carbon saturation concept. Glob Change Biol 21(9):3200-3209. https://doi.org/10.1111/gcb.12982

Cotrufo MF, Wallenstein MD, Boot CM, Denef K, Paul E (2013) The Microbial Efficiency-Matrix Stabilization (MEMS) framework integrates plant litter decomposition with soil organic matter stabilization: do labile plant inputs form stable soil organic matter? Glob Change Biol 19(4):988-995. https://doi.org/10.1111/gcb.12113

Craine JM, Morrow C, Fierer N (2007) Microbial nitrogen limitation increases decomposition. Ecology 88(8):2105-2113. https://doi.org/10.1890/06-1847.1

Dungait JA, Hopkins DW, Gregory AS, Whitmore AP (2012) Soil organic matter turnover is governed by accessibility not recalcitrance. Glob Change Biol 18(6):1781-1796. https://doi.org/10.1111/j.1365-2486.2012.02665.x

Geyer KM, Kyker-Snowman E, Grandy AS, Frey SD (2016) Microbial carbon use efficiency: accounting for population, community, and ecosystem-scale controls over the fate of metabolized organic matter. Biogeochemistry 127(2-3):173-188. https://doi.org/10.1007/s10533-0160191-y

Goldfarb K, Karaoz U, Hanson C, Santee C, Bradford M, Treseder K, Wallenstein M, Brodie E (2011) Differential growth responses of soil bacterial taxa to carbon substrates of varying chemical recalcitrance. Front Microbiol. https:// doi.org/10.3389/fmicb.2011.00094

Hättenschwiler S, Tiunov AV, Scheu S (2005) Biodiversity and litter decomposition in terrestrial ecosystems. Annu Rev Ecol Evol Syst 36(1):191-218. https://doi.org/10.1146/ annurev.ecolsys.36.112904.151932

Hemingway JD, Rothman DH, Grant KE, Rosengard SZ, Eglinton TI, Derry LA, Galy VV (2019) Mineral protection regulates long-term global preservation of natural organic carbon. Nature 570(7760):228-231. https://doi.org/10. 1038/s41586-019-1280-6

Hessen DO, Ågren GI, Anderson TR, Elser JJ, de Ruiter PC (2004) Carbon sequestration in ecosystems: the role of stoichiometry. Ecology 85(5):1179-1192. https://doi.org/ 10.1890/02-0251

IUSS Working Group WRB (2014) World Reference Base for Soil Resources 2014. International soil classification system for naming soils and creating legends for soil maps. World Soil Resources Reports No. 106. FAO, Rome

Janssens IA, Dieleman W, Luyssaert S, Subke JA, Reichstein M, Ceulemans R, Ciais P, Dolman AJ, Grace J, Matteucci G, Papale D, Piao SL, Schulze ED, Tang J, Law BE (2010) Reduction of forest soil respiration in response to nitrogen deposition. Nat Geosci 3(5):315-322. https://doi.org/10. 1038/ngeo844

Kalbitz K, Solinger S, Park J-H, Michalzik B, Matzner E (2000) Controls on the dynamics of dissolved organic matter in soils: a review. Soil Sci 165(4):277-304

Kallenbach CM, Grandy AS, Frey SD, Diefendorf AF (2015) Microbial physiology and necromass regulate agricultural soil carbon accumulation. Soil Biol Biochem 91:279-290. https://doi.org/10.1016/j.soilbio.2015.09.005

Kallenbach CM, Frey SD, Grandy AS (2016) Direct evidence for microbial-derived soil organic matter formation and its ecophysiological controls. Nat Commun 7:13630. https:// doi.org/10.1038/ncomms13630

Krishna MP, Mohan M (2017) Litter decomposition in forest ecosystems: a review. Energy Ecol Environ 2(4):236-249. https://doi.org/10.1007/s40974-017-0064-9

Kuzyakov Y, Friedel JK, Stahr K (2000) Review of mechanisms and quantification of priming effects. Soil Biol Biochem 32(11):1485-1498. https://doi.org/10.1016/S00380717(00)00084-5

Lajtha K, Bowden RD, Crow S, Fekete I, Kotroczó Z, Plante A, Simpson MJ, Nadelhoffer KJ (2018) The detrital input and removal treatment (DIRT) network: insights into soil carbon stabilization. Sci Total Environ 640:1112-1120. https://doi.org/10.1016/j.scitotenv.2018.05.388

Liang C, Schimel JP, Jastrow JD (2017) The importance of anabolism in microbial control over soil carbon storage. Nat Microbiol 2(8):17105. https://doi.org/10.1038/ nmicrobiol.2017.105

Ludwig M, Achtenhagen J, Miltner A, Eckhardt K-U, Leinweber P, Emmerling C, Thiele-Bruhn S (2015) Microbial contribution to SOM quantity and quality in density fractions of temperate arable soils. Soil Biol Biochem 81:311-322. https://doi.org/10.1016/j.soilbio.2014.12.002

Luo Z, Viscarra Rossel RA, Shi Z (2020) Distinct controls over the temporal dynamics of soil carbon fractions after land 
use change. Glob Change Biol 26(8):4614-4625. https:// doi.org/10.1111/gcb. 15157

Manning P, Saunders M, Bardgett RD, Bonkowski M, Bradford MA, Ellis RJ, Kandeler E, Marhan S, Tscherko D (2008) Direct and indirect effects of nitrogen deposition on litter decomposition. Soil Biol Biochem 40(3):688-698. https:// doi.org/10.1016/j.soilbio.2007.08.023

Manzoni S, Taylor P, Richter A, Porporato A, Agren GI (2012) Environmental and stoichiometric controls on microbial carbon-use efficiency in soils. New Phytol 196(1):79-91. https://doi.org/10.1111/j.1469-8137.2012.04225.x

Miller RM, Jastrow JD (2000) Mycorrhizal fungi influence soil structure. In: Kapulnik Y, Douds DD (eds) Arbuscular mycorrhizas: physiology and function. Springer, Dordrecht, pp 3-18

Moinet GYK, Hunt JE, Kirschbaum MUF, Morcom CP, Midwood AJ, Millard P (2018) The temperature sensitivity of soil organic matter decomposition is constrained by microbial access to substrates. Soil Biol Biochem 116:333-339. https://doi.org/10.1016/j.soilbio.2017.10. 031

Moorhead DL, Sinsabaugh RL (2006) A theoretical model of litter decay and microbial interaction. Ecol Monogr 76(2):151-174. https://doi.org/10.1890/00129615(2006)076[0151:ATMOLD]2.0.CO;2

Nadelhoffer KJ, Emmett BA, Gundersen P, Kjønaas OJ, Koopmans CJ, Schleppi P, Tietema A, Wright RF (1999) Nitrogen deposition makes a minor contribution to carbon sequestration in temperate forests. Nature 398(6723):145-148. https://doi.org/10.1038/18205

Neff JC, Townsend AR, Gleixner G, Lehman SJ, Turnbull J, Bowman WD (2002) Variable effects of nitrogen additions on the stability and turnover of soil carbon. Nature 419(6910):915-917. https://doi.org/10.1038/nature01136

Oades JM, Kirkman MA, Wagner GH (1970) The use of gasliquid chromatography for the determination of sugars extracted from soils by sulfuric acid. Soil Sci Soc Am J 34(2):230-235. https://doi.org/10.2136/sssaj1970. $03615995003400020017 x$

Oksanen J, Blanchet FG, Friendly M, Kindt R, Legendre P, McGlinn D, Minchin PR, Ohara R, Simpson GL, Solymos $P$ (2016) Vegan: community ecology package. R package version 2.4-3. R Foundation for Statistical Computing, Vienna

Poeplau C, Helfrich M, Dechow R, Szoboszlay M, Tebbe CC, Don A, Greiner B, Zopf D, Thumm U, Korevaar H, Geerts R (2019) Increased microbial anabolism contributes to soil carbon sequestration by mineral fertilization in temperate grasslands. Soil Biol Biochem 130:167-176. https://doi. org/10.1016/j.soilbio.2018.12.019

R Development Core team (2018) A language ans environment for statistical computing. R Found Stat Comput, Vienna

Ramirez KS, Craine JM, Fierer N (2010) Nitrogen fertilization inhibits soil microbial respiration regardless of the form of nitrogen applied. Soil Biol Biochem 42(12):2336-2338. https://doi.org/10.1016/j.soilbio.2010.08.032

Reay DS, Dentener F, Smith P, Grace J, Feely RA (2008) Global nitrogen deposition and carbon sinks. Nat Geosci 1(7):430-437. https://doi.org/10.1038/ngeo230

Rovira P, Vallejo VR (2002) Labile and recalcitrant pools of carbon and nitrogen in organic matter decomposing at different depths in soil: an acid hydrolysis approach. Geoderma 107(1):109-141. https://doi.org/10.1016/ S0016-7061(01)00143-4

Sayer EJ, Heard MS, Grant HK, Marthews TR, Tanner EVJ (2011) Soil carbon release enhanced by increased tropical forest litterfall. Nat Clim Change 1(6):304-307. https://doi. org/10.1038/nclimate 1190

Scharlemann JPW, Tanner EVJ, Hiederer R, Kapos V (2014) Global soil carbon: understanding and managing the largest terrestrial carbon pool. Carbon Manag 5(1):81-91. https://doi.org/10.4155/cmt.13.77

Schmidt MW, Torn MS, Abiven S, Dittmar T, Guggenberger G, Janssens IA, Kleber M, Kögel-Knabner I, Lehmann J, Manning DA (2011) Persistence of soil organic matter as an ecosystem property. Nature 478(7367):49-56. https:// doi.org/10.1038/nature 10386

Shen D, Ye C, Hu Z, Chen X, Guo H, Li J, Du G, Adl S, Liu M (2018) Increased chemical stability but decreased physical protection of soil organic carbon in response to nutrient amendment in a Tibetan alpine meadow. Soil Biol Biochem 126:11-21. https://doi.org/10.1016/j.soilbio.2018. 08.008

Sinsabaugh RL, Manzoni S, Moorhead DL, Richter A (2013) Carbon use efficiency of microbial communities: stoichiometry, methodology and modelling. Ecol Lett 16(7):930-939. https://doi.org/10.1111/ele.12113

Sinsabaugh RL, Turner BL, Talbot JM, Waring BG, Powers JS, Kuske CR, Moorhead DL, Follstad Shah JJ (2016) Stoichiometry of microbial carbon use efficiency in soils. Ecol Monogr 86(2):172-189. https://doi.org/10.1890/15-2110.1

Six JCP, Lenders S (2000) Soil macroaggregate turnover and microaggregate formation: a mechanism for $\mathrm{C}$ sequestration under no-tillage agriculture. Soil Biol Biochem 32(14):2099-2103. https://doi.org/10.1016/S00380717(00)00179-6

Six J, Elliott ET, Paustian K, Doran JW (1998) Aggregation and soil organic matter accumulation in cultivated and native grassland soils. Soil Sci Soc Am J 62(5):1367-1377. https://doi.org/10.2136/sssaj1998. $03615995006200050032 x$

Sun XL, Zhao J, You YM, Jianxin Sun O (2016) Soil microbial responses to forest floor litter manipulation and nitrogen addition in a mixed-wood forest of northern China. Sci Rep 6:19536. https://doi.org/10.1038/srep19536

Thornton PE, Lamarque J-F, Rosenbloom NA, Mahowald NM (2007) Influence of carbon-nitrogen cycle coupling on land model response to $\mathrm{CO}_{2}$ fertilization and climate variability. Glob Biogeochem Cycles 21(4):4018. https://doi.org/10. 1029/2006GB002868

Tian Q, Yang X, Wang X, Liao C, Li Q, Wang M, Wu Y, Liu F (2016) Microbial community mediated response of organic carbon mineralization to labile carbon and nitrogen addition in topsoil and subsoil. Biogeochemistry 128(1-2):125-139. https://doi.org/10.1007/s10533-0160198-4

Treseder KK (2008) Nitrogen additions and microbial biomass: a meta-analysis of ecosystem studies. Ecol Lett 11(10):1111-1120. https://doi.org/10.1111/j.1461-0248. 2008.01230.x

van Groenigen KJ, Forristal D, Jones M, Smyth N, Schwartz E, Hungate B, Dijkstra P (2013) Using metabolic tracer 
techniques to assess the impact of tillage and straw management on microbial carbon use efficiency in soil. Soil Biol Biochem 66:139-145. https://doi.org/10.1016/j. soilbio.2013.07.002

Vance E, Brookes P, Jenkinson D (1987) An extraction method for measuring soil microbial biomass C. Soil Biol Biochem 19(6):703-707. 0717(87)90052-6

von Haden AC, Kucharik CJ, Jackson RD, Marín-Spiotta E (2019) Litter quantity, litter chemistry, and soil texture control changes in soil organic carbon fractions under bioenergy cropping systems of the North Central U.S. Biogeochemistry 143(3):313-326. https://doi.org/10.1007/ s10533-019-00564-7

von Lützow M, Kogel-Knabner I, Ekschmitt K, Matzner E, Guggenberger G, Marschner B, Flessa H (2006) Stabilization of organic matter in temperate soils: mechanisms and their relevance under different soil conditions-a review. Eur J Soil Sci 57(4):426-445. https://doi.org/10. 1111/j.1365-2389.2006.00809.x von Lützow M, Kögel-Knabner I, Ekschmitt K, Flessa H, Guggenberger G, Matzner E, Marschner B (2007) SOM fractionation methods: relevance to functional pools and to stabilization mechanisms. Soil Biol Biochem 39(9):2183-2207. https://doi.org/10.1016/j.soilbio.2007. 03.007

You Y, Wang J, Huang X, Tang Z, Liu S, Sun OJ (2014) Relating microbial community structure to functioning in forest soil organic carbon transformation and turnover. Ecol Evol 4(5):633-647. https://doi.org/10.1002/ece3.969

Zhang Y, Zou J, Meng D, Dang S, Zhou J, Osborne B, Ren Y, Liang T, Yu K (2020) Effect of soil microorganisms and labile $\mathrm{C}$ availability on soil respiration in response to litter inputs in forest ecosystems: a meta-analysis. Ecol Evol 00:1-11. https://doi.org/10.1002/ece3.6965

Publisher's Note Springer Nature remains neutral with regard to jurisdictional claims in published maps and institutional affiliations. 